\title{
Ultrasound-guided single shot preemptive erector spinae plane block for thoracic surgery in a pediatric patient
}

\author{
Pediatrik hastada preemtif erector spina plan bloğunun toraks cerrahisi sonrası \\ analjezik etkinliği
}

(ㄷ) Bahadır ÇifTÇi, (1) Mürsel EKinci

To the Editor,

The ultrasound-guided erector spinae plane block (ESPB) is a novel interfascial plane block that provides thoracic analgesia at T5 level. ESPB is easy to perform and it is safe due to USG guidance. ${ }^{[1]}$ Thus, ESPB may be a good alternative to other invasive techniques, such as thoracal epidural analgesia in the postoperative analgesia treatment following thoracic surgery. In this correspondence, our aim is to present our effective ESPB experience for a pediatric patient.

Written informed consent was obtained from the patient's parent for this report. A 12-year-old, $43 \mathrm{~kg}$ male patient underwent right lung wedge resection due to lung metastasis of liver carcinoma. General anesthesia was induced and the patient was entubated. Then, he was placed in the left lateral decubitis position for surgery. A linear ultrasound probe (12 MHz, GE Vivid $Q^{\circledR}$ USG device) was placed in a sagittal paramedian orientation at the level of the T5 transverse process for unilateral ESPB (Fig. 1a). The muscles (trapezius, rhomboid major, and erector spinae) were seen from superficial to deep above the hyperechoic transverse process view (Fig. 1b). Then, a block needle (22-gauge, 50-mm, SonoTap; Braun, Stimuplex ${ }^{\circledast}$ Ultra, Germany) was attached in the interfascial plane below the erector spinae muscle in a caudal-to-cephalad way. After aspiration, the plane was injected with $2 \mathrm{ml}$ saline solution for correction. A total of $15 \mathrm{~mL}$ block solution prepared with $0.25 \%$ bupivacaine was administrated (Fig. 1c). We performed a single shot block and did not use a block catheter for continuous infusion. $75 \mu \mathrm{g}$ of fentanyl and $400 \mathrm{mg}$ of paracetamol intravenously were administered intraoperatively. The patient was extubated at the end of the operation and transferred to the postanesthesia care unit (PACU). The pain score (VAS) was 0 at PACU. Another additional analgesic was not performed to him. $400 \mathrm{mg}$ of paracetamol iv was administrated at every eight hours for postoperative analgesia. An intravenous patient controlled device prepared with $5 \mathrm{mcg} / \mathrm{ml}$ fentanyl was
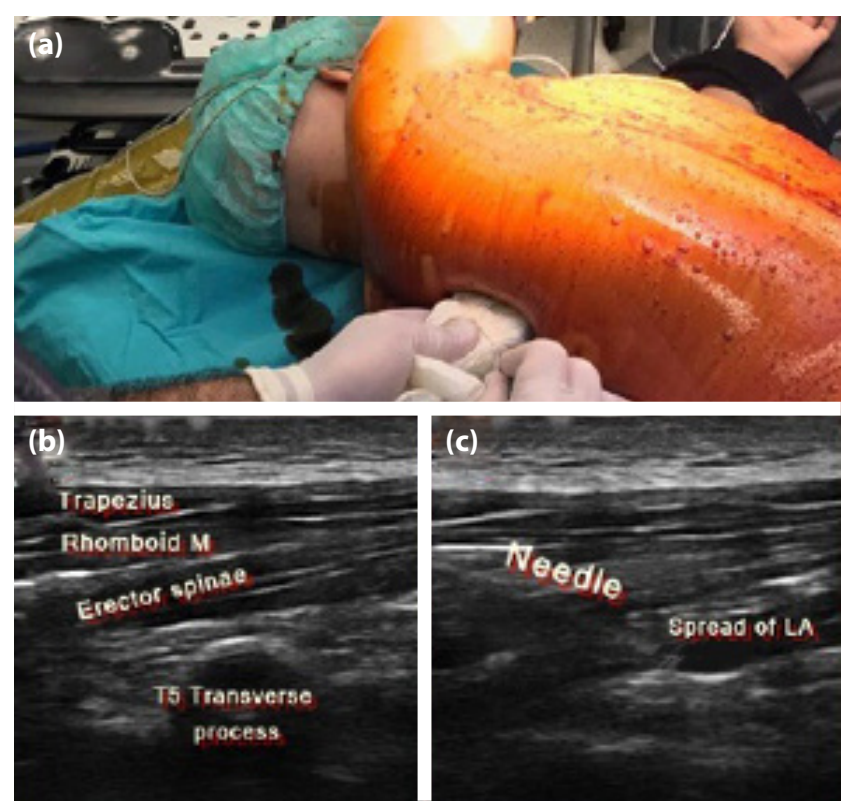

Figure 1. (a) Block preparation. (b) Sonographic anatomy. (c) Spread of local anesthetic. (below erector spinae muscle, above the transverse process).

Department of Anesthesiology and Reanimation, Istanbul Medipol University, Istanbul, Turkey

Submitted (Başvuru tarihi) 17.01.2019 Accepted after revision (Düzeltme sonrası kabul tarihi) 17.01.2019 Available online date (Online yayımlanma tarihi) 28.05.2019

Correspondence: Dr. Bahadır Çiftçi. İstanbul Medipol Üniversitesi Tıp Fakültesi, Anesteziyoloji ve Reanimasyon Anabilim Dalı, İstanbul, Turkey.

Phone: +90 - 532 - 5034428 e-mail: baha_cftci@hotmail.com

(c) 2020 Turkish Society of Algology 
attached to the patient with a protocol included 10 mcg bolus without infusion dose, 10 min lockout time and 4-hour limit. During the postoperative period, the PCA bolus dose administered was only three times. No other rescue medication was needed. Oral $300 \mathrm{mg}$ of ibuprofen with a dose of $3 \times 1$ was administered after 48 hours form the surgery.

A local anesthetic injection was performed for ESPB into the paraspinal tissues. This area is away from the important structures (pleural and neurological), so the risk of complications is lower due to injury. ${ }^{[2]} \mathrm{An}$ atomical guide points can be seen easily under USG guidance, and the spread of local anesthetics can be visualized below the erector spinae muscle. Therefore, analgesia occurs in several dermatomes at anterolateral and posterior of the thorax. ${ }^{[1,3]}$ Especially in pediatric patients, central neuraxial blocks are not generally preferred because of the difficulty of application. Therefore, ESP block for pediatric patients may be a good alternative for postoperative analgesia management after painful procedures, such as thoracic surgery.
We wanted to see the effectiveness of the singledose preemptive ESP block for pediatric thoracic surgery. Thus, we did not use a catheter. VAS scores were below 4 in postoperative period and any more rescue analgesia was not performed. In conclusion, preemptive single shot ESP block can be performed as a part of multimodal analgesia treatment for postoperative analgesia management after pediatric thoracic surgery since it is easy to use, and provides effective analgesia.

\section{References}

1. Forero M, Adhikary SD, Lopez H, Tsui C, Chin KJ. The erector spinae plane block: a novel analgesic technique in thoracic neuropathic pain. Reg Anesth Pain Med 2016;41(5):621-7. [CrossRef]

2. Forero M, Rajarathinam M, Adhikary S, Chin KJ. Continuous erector spinae plane block for rescue analgesia in thoracotomy after epidural failure: a case report. A A Case Rep 2017;8(10):254-6. [CrossRef]

3. Chin KJ, Malhas L, Perlas A. The erector spinae plane block provides visceral abdominaanalgesia in bariatric surgery: a report of 3 cases. Reg Anesth Pain Med 2017;42(3):3726. [CrossRef] 